\title{
Potential Anti-Fouling Properties of Extracts from the Mediterranean Sponge Ircinia Oros: An Ecotoxicological Screening
}

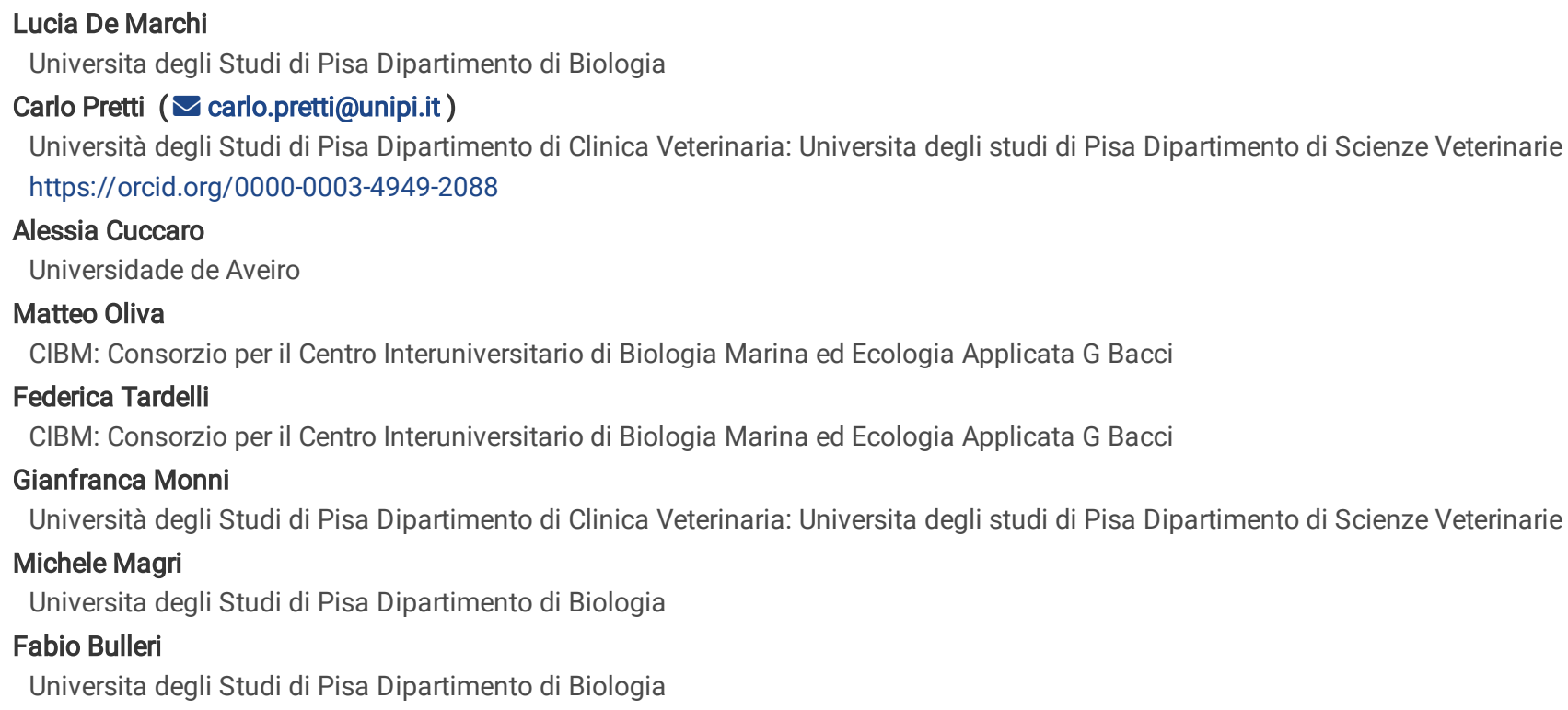

Research Article

Keywords: sponge' extract, ecotoxycological screening, bioassay, antifouling, Ficopomatus enigmaticus, development stages

Posted Date: June 4th, 2021

DOI: https://doi.org/10.21203/rs.3.rs-513755/v1

License: (ㄷ) (1) This work is licensed under a Creative Commons Attribution 4.0 International License. Read Full License

Version of Record: A version of this preprint was published at Environmental Science and Pollution Research on August 5th, 2021. See the published version at https://doi.org/10.1007/s11356-021-15683-8. 


\section{Abstract}

The phylum Porifera and their symbionts produce a wide variety of bioactive compounds, playing a central role in their ecology and evolution. In this study, four different extracts (obtained by non-polar and semi-polar extraction methodologies) from the Mediterranean sponge Ircinia oros were tested for their potential antifouling purposes. The evaluation was performed using three different target species, associated with three different endpoints: the marine bacterium Aliivibrio fischeri (inhibition of bioluminescence), the marine diatom Phaeodacty/um tricornutum (inhibition of growth) and different development stages of the brackish-water serpulid Ficopomatus enigmaticus (gametes: sperm motion, vitality inhibition and cellular damage; larvae: development; adults: AChE (acetylcholinesterase)-inhibitory activity). Effects of extracts were species-specific and did not vary among different extraction methodologies. In particular, no significant reduction of bioluminescence of $A$. fischeri was observed for all tested samples. By contrast, extracts inhibited $P$. tricornutum growth and had toxic effects on different $F$. enigmaticus' developmental stages. Obtained results suggest that the proposed test battery can be considered a suitable tool as bioactivity screening of marine natural products.

\section{Introduction}

Marine sponges (Porifera) are an ancient metazoan group and a major component of benthic fauna throughout temperate, tropical and polar environments (Bell, 2008). Sponges are benthic sessile organisms, attached to rocky surfaces or shells and are present both in open seas and estuaries (Chậtel et al., 2011). Sponges provide key ecological services, including reworking of solid carbonate through bioerosion, nutrient recycling, primary production through microbial symbionts, clearance of the water column of prokaryotic plankton and food for other organisms (Wulff, 2006). Sponges are active suspension feeders with the capability of absorbing $\approx 80 \%$ of suspended particles dissolved in the water column or present in sediments (Reiswig, 1974; Müller and Müller, 1998). By this mechanism, they are able to accumulate dissolved or suspended pollutants such as detergents (Zahn et al., 1977), polychlorinated biphenyls (PCBs) (Efremova et al., 2002), trace elements (Müller and Müller, 1998; Rao et al., 2006; Cebrian et al. 2007; Gentric et al., 2016) polycyclic aromatic hydrocarbons (PAHs) (Batista et al., 2013), surfactants, organochlorines (Perez et al., 2002; 2003), organophosphorus and carbamates (Marques et al., 2007).

In addition, sponges and their symbionts can exhibit chemical defence mechanisms against predation or epibiont overgrowth, often referred to as epibiosis or biofouling (Takur and Anil, 2000; Tsoukatou et al., 2002; Hellio et al., 2005; Sánchez-Lozano et al., 2019). Biofouling on marine infrastructure, introduced to sustain a variety of maritime activities, including industry, shipping, energy production, fishing or aquaculture can cause substantial economic loss (Eguía et al., 2007; Hellio et al., 2005; Sánchez-Lozano et al., 2019; Vigneron et al., 2018). In order to reduce or slow down biofouling, paints based on different chemical form of copper/zinc together with booster biocides (Eguía et al., 2007) have been and are still widely used. However, adverse environmental effects caused by these chemical compounds have been extensively demonstrated (Santillo et al., 2001; Thomas and Brooks, 2010; Hasan et al., 2014; Batista-Andrade et al., 2018). Thus, the use of natural marine products able to reduce the recruitment and growth of fouling species on submerged structures may represent an innovative, nature-based solution to enhance the quality of marine urban ecosystems, such as marinas and ports.

Sponges represent a dominant component of Mediterranean benthic communities, with approximatively 720 species (Costa et al., 2018 ). In particular, the genus Ircinia spp. is widely distributed on shallow rocky reefs in the Mediterranean Sea (Riesgo et al., 2016). This horny sponge, with a highly variable and irregular growth form, can reach up to $30 \mathrm{~cm}$ in diameter (Ledda et al., 2014). Ircinia spp. is a source of bioactive metabolites, such as linear or cyclic polyprenyl hydroquinones (Mihopoulos et al., 1999) and sesterterpenes (Cimino et al., 1972), many of which contain furan and tetronic acid functional groups. These metabolites can have antimicrobial and enzyme inhibitory activities (Duque et al., 2001; Thakur et al., 2004, Beedessee et al., 2013), as well as the ability to inhibit the growth of micro- and macro-algae (Tsoukatou et al., 2002) and the settlement of mussels, polychaetes and barnacles (Tsoukatou et al., 2002, Hellio et al., 2005, Sánchez-Lozano et al., 2018).

In this study, two bioassays canonically adopted in ecotoxicological testing, namely Aliivibrio fischeri (bacteria) inhibition of bioluminescence and Phaeodactylum tricornutum (diatom) inhibition of growth, were adopted for toxicity evaluation of Ircinia oros extracts. Moreover, the promising potential of these extracts was evaluated through an integrated approach, performing a series of assays at different development stages (gametes, larvae and adults) of the serpulid Ficopomatus enigmaticus, an invasive fouler able to colonize vessels and all submerged hard-substrata, forming massive reefs which removal implies considerable economic costs. In particular, we investigated how extracts affected sperm motion, vitality inhibition and cellular damage, larval development and neuro-enzyme inhibitory activity at the adult stage. In addition, we assessed differences in the effectiveness of non-polar and semi-polar extraction.

\section{Material And Methods}

\subsection{Species collection}

Ircinia oros specimen were collected at the end of September 2020 by SCUBA diving at 10-12.5 m depth along the north-east coast of Elba Island (Nisportino, $42^{\circ} 50.160^{\prime} \mathrm{N} ; 10^{\circ} 23.152^{\prime} \mathrm{E}$, Italy; salinity $40 \%$, temperature $21^{\circ} \mathrm{C}$, pH 8.09$)$. Two fragments $\left(15 \times 10 \mathrm{~cm}^{2}\right.$ each) were inserted into a sterile plastic bag filled in with seawater and immediately transported to the laboratory. Samples were photographed in situ for better species characterization and a small piece was used for taxonomy confirmation. 


\subsection{Preparation of Extracts}

Following Hellio et al. (2005), after collection, samples were rinsed with sterile seawater to remove associated debris. The surface microflora was removed by washing the sponge samples for 10 minutes with ethanol (30\%) and then cut into small pieces, weighted, and freeze-dried. The methodology of extraction was performed based on Beedessee et al. (2013) and Tsoukatou et al. (2002), which is a specific method adopted for the genus Ircinia spp. Briefly, a first batch of dried sponges (20-40 g) was macerated with $\mathrm{MeOH} / \mathrm{CH}_{2} \mathrm{Cl}_{2}$ 1:1 for 24-48 h. After maceration, the solution was filtered and evaporated to dryness on a rotatory vacuum evaporator set at a temperature of $40^{\circ} \mathrm{C}$. This crude extract, which was dissolved in distilled $\mathrm{H}_{2} \mathrm{O}$, was partitioned subsequently with hexane (non-polar solvent) and ethanol ethylacetate (AcOEt) (semi-polar solvent). A second batch of wet sponges (102-120 g) was macerated and partitioned in the same way as described for the first batch. The extracts (10 mg/mL) were resuspended in DMSO and stored at $-20^{\circ} \mathrm{C}$ until the use. Stock solutions were then prepared in artificial seawater (ASW), according to ISO 10253 (2016). For each of the four extracts (dry sponges portioned with hexane (DH) and AcOEt (DA); wet sponges portioned with hexane (WH) and AcOEt (WA)), nominal concentrations were: 100-50-25-10-5-1-0.5-0.25-0.1-0.05 $\mu \mathrm{g} / \mathrm{mL}$. For each extract, the range of concentrations was based: I) on a previous study by Hellio et al. (2005), and II) to determine the limit of tolerance of each tested species, allowing the determination of EC ${ }_{50}$.

\subsection{Ecotoxicological assays}

The ecotoxicological evaluations were performed using three species associated with three different endpoints: the marine bacterium Aliivibrio fischeri (endpoint: inhibition of bioluminescence), the marine diatom Phaeodactylum tricornutum (endpoint: inhibition of growth) and the brackish water serpulid Ficopomatus enigmaticus at different development stages (gamete endpoints: sperm motion, vitality inhibition and cellular damage; larvae endpoint: larval development; adults endpoint: AChE (acetylcholinesterase)-inhibitory activity).

\subsubsection{Inhibition of bioluminescence in Aliivibrio fischeri}

The luminescent bacteria test was performed in accordance with the ISO 11348, 2007 methodology. The bacteria (strain n. 19A4002A, Ecotox LDS, Pregnana Milanese, MI, Italy) was purchased as freeze-dried bacterial cells. Dried bacteria were resuspended in $1 \mathrm{~mL}$ of Reconstitution Solution, acquired together with bacteria vials, in order to reactivate them. At first, a screening test was performed exposing reconstituted $A$. fischeri' suspensions to highest concentrations of all extracts $(100 \mu \mathrm{g} / \mathrm{mL})$ measuring differences in bioluminescence emission (percentage of bioluminescence inhibition - I \%) with control (ASW) after 30 min of exposure. Ultraviolet filters showing an I \% $>20 \%$ were investigated with a full

test in order to calculate $\mathrm{EC}_{10 / 20 / 50}$. Then, $A$. fischeri bacteria were exposed to dilution series (see Sect. 2.3) (in ASW, salinity 30) and bioluminescence was again determined after $30 \mathrm{~min}$ of exposure. Tests were carried out in triplicate, at $15^{\circ} \mathrm{C}$, with sample pH within the operative range (6-8). All measurements were performed with a M500 luminometer, acquisition and data processing $\left(\mathrm{EC}_{10 / 20 / 50}\right.$ calculated by Least Square method) were performed with the Microtox ${ }^{\circledR}$ Omni 1.16 software. The reference toxicant was zinc sulfate eptahydrate (ISO 11348, 2007) and results obtained for this assay fell into the laboratory control chart (6.88-12.45 $\left.\mathrm{mg} / \mathrm{L} \mathrm{Zn}^{2+}\right)$.

\subsubsection{Growth inhibition in Phaeodactylum tricornutum}

The assessment of growth inhibition in P. tricornutum was performed following ISO procedures, with slight changes to the base protocol (ISO 10253 , 2016). Briefly, P. tricornutum Bholin (CCAP 1052/1A) was the test strain, purchased from the reference center CCAP (Culture Collection of Alga and Protozoa Scottish Association for Marine Science/SAMS Research Services Ltd). Enriched Saltwater Medium (ASTM- ESM, ASTM E1218, 2012) was used for culturing $P$. tricornutum algae. The algal batch was prepared $72 \mathrm{~h}$ before the test, obtaining a logarithmic-phase algal culture. After $72 \mathrm{~h}$, the batch was diluted to obtain a concentration of $10^{6} \mathrm{cell} / \mathrm{mL}$. A sample of each sponge' extract was diluted in ASTM-ESM to obtain all working concentrations, as reported in Sect. 2.3. Using 24-well plates, $20 \mu \mathrm{L}$ of diluted algal batch were inoculated in each of three $2 \mathrm{~mL}$ replicates for both samples and controls (ASTM-ESM). Plates were left at $20 \pm 2{ }^{\circ} \mathrm{C}$, under continuous illumination (6000-8000 lx) and slow shaking (80 rpm) for $72 \mathrm{~h}$. Growth after $72 \mathrm{~h}$ of exposure was the evaluated endpoint. Absorbance was measured spectrophotometrically at $670 \mathrm{~nm}$ (Abs670). Algal concentration (Cells* $\mathrm{mL}^{-1}$ ) was calculated from absorbance using the following equation:

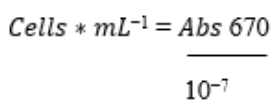

Values of $\mathrm{EC}_{10 / 20 / 50}$ for all extracts were calculated with the Linear Interpolation Method for Sublethal Toxicity software (U.S.EPA,1993). The reference toxicant was potassium dichromate (ISO 10253, 2016), results obtained for this assay fell into the laboratory control chart (1.94-4.36 $\left.\mathrm{mg} / \mathrm{L} \mathrm{Cr}^{2+}\right)$.

\subsubsection{Assays on gametes, larvae and adult in Ficopomatus enigmaticus}

The brackish water serpulid. F. enigmaticus was collected in S. Rossore-Migliarino Regional Park - Fiume Morto (Pisa, Italy) at the end of October 2020. The reef was transferred to the laboratory covered in a wet towel. Water from the sampling site were used to setup the aquaria. In laboratory, the salinity was increased up to a maximum of 5 points/day, until reaching $30 \%$ (Oliva et al., 2018). During this period (temperature $22 \pm 1^{\circ} \mathrm{C}$, oxygen 
saturation > $90 \%$, salinity 30\%o, pH $8.1 \pm 0.1$, photoperiod - 10 h light: 14 h darkness), organisms were daily fed with an Isochrysis galbana algal suspension $\left(1 \times 10^{4}\right.$ cells $\left./ \mathrm{mL}\right)$.

\subsubsection{Gametes}

The spawning of $F$. enigmaticus was induced mechanically by breaking the calcareous tube. According to Oliva et al. (2018), individuals were extracted from their tubes and placed one perwell in a 24-well plate filled with $0.5 \mathrm{~mL}$ of ASW. The destructive method induced the gamete emission within 10 minutes. Pool of sperm suspensions were collected and put together in a sterile test tube and sperm concentration was determined by using a Burker counting chamber and an Olympus $\mathrm{CH}-2$ optical microscope.

After gamete emission (Oliva et al. 2018), $200 \mu \mathrm{L}$ of sperm suspension was incubated for 30 min at room temperature (RT) with $20 \mu \mathrm{L}$ of tested concentrations (10-fold concentrated stock solutions) of each sponge' extracts (see Sect. 2.3). The sperm motion assay was performed according to Elsayed et al. (2015), using the CASA plugin (computer-assisted sperm analysis system, University of California and Howard Hughes Medical Institute, USA) within the ImageJ software (a free open-source image processing software provided by the National Institutes of Health, http://imagej.nih.gov/ij/). Briefly, the incubated sperm suspensions were added with bovine serum albumin (BSA) 1\% (v/v 1:1), placed on microscope glass slides and then examined under a Leica DMi1 inverted microscope, equipped with a MC120-HD camera, using a 40X magnification objective. The video camera recorded for $5 \mathrm{sec}$. (100 frame/s) the moving images (three videos per condition) of sperm cells and the computer digitized them. Digitized images consisted of pixels whose changing locations were recorded frame by frame after the exposure. The images were then processed using the CASA system. The values for input parameters in the CASA dialogue box were set according to a protocol developed by evo-devo-eco network (EDEN, http://edenrcn.com/), with modifications of the sperm size and FPS (number of frames/s) in order to accurately detect motile spermatozoa. CASA system performs its motion analysis through four main steps: (1) capturing image sequences of sperm, (2) object detection, (3) object tracking, and (4) calculation of motion characteristics such as: curvilinear velocity (VCL); average path velocity (VAP); straight-line velocity (VSL); Linearity (LIN), which is the result of the rate between VSL and VAP; Wobble (WOB), which is a measure of sperm head side to side movement and it is the result of the rate between VAP and VCL; Progression (PROG) which represents the distance sperm traveled on VAP path; Beat cross frequency (BCF). The total percentage of sperms that were actively swimming (percentage of motility) were also calculated with CASA systems and the differences between control and exposed spermatozoids at each of the extraction method was performed.

A battery of sperm quality biomarkers (sperm vitality (MTT), lipid peroxidation (LPO), intracellular reactive oxygen species (ROS) and DNA damage) was adopted to assess the spermiotoxic effect of all tested extracts at all concentrations in F. enigmaticus, according to Cuccaro et al. (2020). Tenfold concentrated stock solutions were prepared in ASW for each tested concentration (see Sect. 2.3). Analyses were performed adding $100 \mu \mathrm{L}$ of extract to $1000 \mu \mathrm{L}$ of sperm suspension for each concentration, which was incubated with for 30 min at room temperature (RT). After the exposure, the solutions were transferred on 96-well plate for sperm quality assessment (Cuccaro et al., 2020).

\subsubsection{Larvae}

The larval development assay was performed according to Oliva et al. (2019). The numbers of normally or abnormally developed larvae were counted to calculate a percentage of poorly developed larvae. The acceptability threshold of the assay was set at $20 \%$ of poorly developed larvae in controls. The mean percentage of poorly developed larvae was calculated for each assessed concentration of all samples. $\mathrm{EC}_{10 / 50}$ values and their $95 \%$ confidence intervals were calculated via PROBIT analysis (Finney, 1971).

\subsubsection{Adults}

Individuals of $F$. enigmaticus were extracted from portions of about $50 \mathrm{~g}$ of calcareous tubes (corresponding to $~ 80$ individuals), weighted and pooled in three replicates (80/90 individuals each). Each pooled sample was pulverized and then homogenized in a potter Elvejem in $100 \mathrm{mM}$

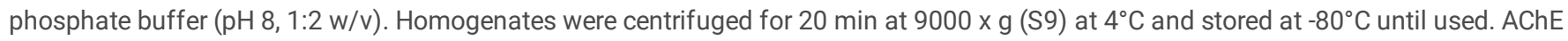
(acetylcholinesterase) activity was measured according to Ellman et al. (1961) in $100 \mathrm{mM}$ phosphate buffer (pH 8.0), $10 \mathrm{mM}$ DTNB, and $24 \mathrm{mM}$ of substrates (ATChl). Enzyme activity was recorded continuously for $5 \mathrm{~min}$ at $412 \mathrm{~nm}$ at $25^{\circ} \mathrm{C}$ in a BioTek Synergy HT micro-plate reader and the specific activity was corrected for the spontaneous hydrolysis of the substrate ( $\mathrm{nmol} / \mathrm{min} / \mathrm{mg}$ protein). Protein content was determined according to the Lowry method (Lowry, 1951) using BSA as standard. For inhibition studies, aliquots of $200 \mu \mathrm{L}$ of S 9 fraction from each pool were incubated with each extract at different concentrations (100-50-25 and $10 \mu \mathrm{g} / \mathrm{mL}$ ) for $30 \mathrm{~min}$ at $25^{\circ} \mathrm{C}$ before measuring the enzyme activities. The residual activity was determined as previously described. The concentration capable of inhibiting half of the enzyme activity (IC ${ }_{50}$ plus $95 \%$ confidence limits) was estimated for each extract.

\subsection{Statistical analyses}

The effects of sponge extract methodology and concentration were tested by means of a two-way ANOVA (GraphPad Prism version 6.00 for Windows, GraphPad Software, La Jolla California USA, www.graphpad.com.) The analysis was followed by a post-test (Bonferroni) for multiple comparison. Statistical analysis was used for all ecotoxicological assays.

\section{Results}




\subsection{Inhibition of bioluminescence in Aliivibrio fischeri}

Since there was no inhibition of $A$. fischeri bioluminescence in response to any of sponge' extracts at tested concentrations ( $<12 \%$ of inhibition at 100 $\mu \mathrm{g} / \mathrm{mL}$ for all tested toxicants), mean $\mathrm{EC}_{10 / 20 / 50}$ with respective $95 \%$ confidence limits are not reported.

\subsection{Growth inhibition in Phaeodactylum tricomutum}

Sponges portioned with hexane (both dry and wet) induced lower $\mathrm{EC}_{10 / 20 / 50}$ values compared those portioned with AcOEt (Table 1 ). In details, $\mathrm{DH}$ presented the lowest $\mathrm{EC}_{50}(9.70 \mu \mathrm{g} / \mathrm{mL})$ followed by WH $(12.17 \mu \mathrm{g} / \mathrm{mL})$. WA and DA extracts $\left(\mathrm{EC}_{50}\right.$ of 38.26 and $42.99 \mu \mathrm{g} / \mathrm{mL}$ respectively) had weaker effects. Calculated values revealed the following increasing order of inhibition effects: $D A>W A>W H>D H$.

\subsection{Assays on gametes, larvae and adult in Ficopomatus enigmaticus}

As a consequence of high abnormal sperm morphology and mortality at 100,50 and $25 \mu \mathrm{g} / \mathrm{mL}$ induced by all tested extracts, the estimation of sperm motion characteristics was performed from a range of concentrations of 10 to $0.5 \mu \mathrm{g} / \mathrm{mL}$ (Table 2). A dose-dependent decrease of all investigated sperm motions (VCL, VAP, VSL, LIN, WOB, PROG and BCF) was caused by all tested extracts.

The ANOVA showed that for the motility assay there was a significantly interaction between concentrations and extracts (15.24\% of the total variance) (Table 3), nonetheless, only the concentration factor significantly effects the motility inhibition (Table 3, Figure 1). In detail, DA and DH showed statistically lower values at both 10 and $5 \mu \mathrm{g} / \mathrm{mL}$, while WA and WH only at $5 \mu \mathrm{g} / \mathrm{mL}$ compared to the respective controls (Figure 1 ).

Although there was an interaction between concentrations and extracts, sperm quality significantly varied only according to concentrations (table 4). Incubation of sperms with increasing concentrations of all extracts resulted in a progressive increase of RoS production, showing statistically higher values of sponges portioned with AcOEt (both dry and wet) at 5 and $10 \mu \mathrm{g} / \mathrm{mL}$ respectively and at concentrations ranging between 0.25 and 1.0 $\mu \mathrm{g} / \mathrm{mL}$ for the $\mathrm{WH}$ (wet sponges portioned with hexane) treatment (Figure $2 \mathrm{~A}$ ).

A dose-dependent increase was also detected in terms of membrane peroxidation levels when sperms were exposed to all extracts, with statistically differences observed under DA, WA and WH treatments. Specifically, for DA, significantly higher LPO levels were detected at 2.5, 5 and $10 \mu \mathrm{g} / \mathrm{mL}$, for WA only at $10 \mu \mathrm{g} / \mathrm{mL}$, and for $\mathrm{WH}$ at concentrations ranging between 0.25 and $5 \mu \mathrm{g} / \mathrm{mL}$ (Figure 2B).

The vitality of sperms (expressed as \% of MTT) was not affected by any of tested extracts (Fig. 2C). Finally, there was a significant DNA damage at two highest concentrations of extracts, respectively at $5 \mu \mathrm{g} / \mathrm{mL}$ for DA and both at 5 and $10 \mu \mathrm{g} / \mathrm{mL}$ for WA treatments (Figure 2D).

\subsubsection{Larvae}

Sponges portioned with hexane (both dry and wet) generally showed lower $\mathrm{EC}_{10 / 50}$ values compared the ones portioned with AcOEt (Table 5). In detail, WH presented the lowest $\mathrm{EC}_{50}(0.89 \mu \mathrm{g} / \mathrm{mL})$ followed by $\mathrm{DH}(1.69 \mu \mathrm{g} / \mathrm{mL})$. WA and DA at EC $\mathrm{F}_{50}$ of 1.21 and $5.12 \mu \mathrm{g} / \mathrm{mL}$ induced weaker effects on larval development, respectively. Calculated $\mathrm{EC}_{50}$ values revealed the following decreasing order of effects: $\mathrm{DA}>\mathrm{WA}>\mathrm{DH}>\mathrm{WH}$.

The ANOVA showed significant effects of extract concentrations on the proportion of larva successfully developed, consistently among extracts (Table 6). Differences were significant between control and the highest concentration (DA and WA) and between the two highest concentrations (DH and $\mathrm{WH}$ ), with successful larval development decreasing as concentrations increased. Moreover, all sponge extracts, when at $10 \mu \mathrm{g} / \mathrm{mL}$, caused a $100 \%$ death of larvae (Figure 3).

\subsubsection{Adults}

Since there was no neurotransmitter inhibition of $F$. enigmaticus fractions incubated at concentrations ranging between 0.05 and $1.0 \mu \mathrm{g} / \mathrm{mL}$ of all extracts, the estimation of the inhibitory activity on the enzyme was examined from 5 to $100 \mu \mathrm{g} / \mathrm{mL}$. Inhibition of the AChE activity varied significantly with extract concentration (Table 7). Increasing extract concentrations significantly raised the percentage of inhibitory effects compared with their respective controls (Figure 4).

\section{Discussion}

Four different extracts obtained from the sponge I. oros were tested investigating their potential antifouling purposes. The extraction methods adopted were selected following Beedessee et al. (2013), who observed that AcOEt extracts of the sponges Pericharax heteroraphis and Amphimedon navalis displayed competitive/non-competitive inhibition associated with terpenoids and steroids (Beedessee et al., 2013). Several studies have shown that sponges are rich in terpenoids and steroids, which can be effective in reducing predation rates (Pawlik, 2012) competition for space (Duque et al., 2001, Pawlik et al., 2007, Helber et al., 2018) and epibiosis (Thakur and Singh, 2016). Specifically, Hellio et al. (2005), found that extracts (the mixture of ircinin I and II sesterterpenes) from epibiont-free specimen of the Mediterranean sponge I. oros, were highly active in inhibiting the settlement of the barnacle Balanus amphitrite (i.e., higher percentage of swimming larvae and lower percentage of settling larvae). 
Sponges have been extensively used as growth bacterial inhibitors. Mol et al (2009), demonstrated that acetone extracts from sponges of the genus Haliclona spp. inhibited the growth of several bacteria, including Bacillus cereus, B. pumilus, B. megaterium, Pseudoalteromonas haloplanktis, Pseudomonas chlororaphis, $P$. putida and $P$. aeruginosa. In this study, none of tested extracts reduced the bioluminescence in the marine bacteria $A$. fischeri in comparison with controls. Although this bioassay has been widely applied for evaluating compound toxicity since it is cost-effective and easy to use (Abbas et al., 2018), a number of studies have reported a low sensitivity for toxicity measurement of some chemicals such as antibiotics and mycotoxins (Abbas et al., 2018).

Different results were obtained testing the same extracts on other species. All four extracts had a calculable $\mathrm{EC}_{10 / 20 / 50}$ on the growth of $P$. tricornutum. Negative effects were stronger for non-polar (with hexane) than semi-polar extracts (AcOEt). Significant bioactivity on microalgae inhibition has also been reported for other screening strategies, such as extracting l. oros metabolites with a polar solvent (ethanol) (Tsoukatou et al., 2002), suggesting their effectiveness in inhibiting microalgal growth.

One of the main concerns about the use of natural chemical compounds is the impact that they can have on non-target organisms (Hasson et al., 2011). For this reason, the effectiveness of four sponge' extracts was evaluated in the non-target serpulid, F. enigmaticus. Considering that the effects of any toxicant can vary across life stages (Mohammed, 2013), extracts were tested on gametes, larvae and adults of $F$. enigmaticus. For a general point of view, all $l$. oros' extracts showed negative effects on sperm kinematics (motion characteristics), even if not concentration-dependent. Considering the percentage of sperm progressive motility, negative concentration -dependent effects were caused by all extracts. Sperm motility is highly dependent on several metabolic pathways and regulatory mechanisms. Any abnormality in these factors could be responsible of poor sperm motility and one of the main causes was already identified in biochemical deficits of sperms (Pereira et al., 2015). To validate this hypothesis, we assessed a battery of biomarkers related to sperm damage (LPO, ROS production and DNA damage) and vitality (MTT). Once again, there was a significant dose-dependent increase in ROS production compared to controls, especially at highest exposure concentrations. Reactive oxygen species (ROS), such as the superoxide anion $\left(\mathrm{O}_{2}^{-}\right)$, hydrogen peroxide $\left(\mathrm{H}_{2} \mathrm{O}_{2}\right)$ and nitric oxide $\left(\mathrm{NO}^{-}\right)$, are chemically reactive molecules resulting from oxygen consumption. At certain concentrations, ROS are of extreme importance to sperm function (Agarwal et al., 2003, Ford, 2004). Specifically, some studies have demonstrated the involvement of ROS in sperm functionality, reporting that $\mathrm{NO}^{-}$induce capacitation at low levels while it blocks sperm motility at high levels. In addition, also high $\mathrm{O}_{2}{ }^{-}$and $\mathrm{H}_{2} \mathrm{O}_{2}$ levels can be deleterious for sperm functionality affecting motility parameters (Herrero et al., 1999, O'Flaherty et al., 1999, Du Plessis et al., 2010, Pereira et al., 2015). In this study, the excessive ROS production was also confirmed by I) the dose-dependent oxidative damage of cellular membranes caused by all sponge extracts and II) the DNA damage observed at highest concentrations of DA and WA extracts (dry and wet $I$. oros portioned with AcOEt). As a matter of fact, the imbalance in the rate of ROS generation leads to oxidative stress. The products of lipid peroxidation chain reactions display high biological activity destroying DNA, proteins, and enzymes as well as activating signaling pathways which cause cell death (Su et al., 2019). Our results could be partly driven by the high abnormal sperm morphology and mortality that emerged at 100, 50 and $25 \mu \mathrm{g} / \mathrm{mL}$ and the consequent use of low concentrations of sponge' extracts, this hypothesis can justify the obtained. However, although the integrity of the membrane and the damage of DNA were significantly correlated with sperm kinematics and motility, as they were related to an increase of excessive ROS, no variation in terms of sperm vitality was detected for all extracts under all exposed concentrations compared to their relative controls.

In this work, the larval development assay was also used as endpoint of extract toxicity. The selected assay was focused on the first developmental stage, which brings zygotes to a planktonic and planctotrophic trocophore stage (Oliva et al., 2018, 2019). Because the first larval development endpoints are commonly considered of high sensitivity to a large number of chemical substances (Azad et al., 2009, Azad, 2013), embryotoxicity tests have become more common. All four extracts showed a statistically significant effect in terms of inhibition of larval development with calculable $\mathrm{EC}_{50 / 10}$ values. However, although no statistical differences were obtained among the different extracts, the sensitivity of larvae to hexane (both dry and wet) was greater (lower $\mathrm{EC}_{50 / 10}$ values) than that to AcOEt extracts. The toxicity assessments of natural mixtures and emerging contaminants was recently applied to F. enigmaticus (Oliva et al., 2018, 2019, 2020), confirming the sensitivity of this organism as well as the embryotoxicity test as a valuable tool in developmental toxicology. Our results are in line with those of Herath et al. (2019), who, using extracts from two marine sponges (Monanchora unguiculata and Haliclona sp.), found significant effects on the development of larvae of the nematode, $H$. contortus, in, particular, a dose-dependent inhibition of the motility of third-stage larvae as well as of the development of the fourth-stage larvae.

The relationship between reduced settlement and development inhibition in sessile organisms generated by sponge extracts, through the alteration of neurotransmitter enzymes activity, has been previously demonstrated (Garaventa et al., 2010). In details, Garaventa et al. (2010) observed that expression of poly-alkylpyridinium salts (poly-APs), a mixture of two polymers obtained from the Mediterranean sponge Haliclona sarai, were able to generate specific and non-toxic acetylcholinesterase (AChE) inhibition in vitro. The substance was first tested for its effect on larval development of A. Amphitrite confirming the ability of Poly-APs to prevent the development of sessile organism by impinging on AChE activity. Our results are in agreement with previous evidence of sponge extract-induced neurotransmitter inhibition, confirming that AChE is an enzyme associated to the cholinergic signal system, but is also involved in cell-to-cell communication, driving embryonic development (Wessler et al., 2008).

\section{Conclusion}

All extracts showed species-specific effects without differences among extraction methodologies. In details, no significant reduction of bioluminescence in $A$. fischeri assay was observed for all tested samples. In contrast, all tested extracts had a significant bioactivity on microalgal 
inhibition, as well as toxic effects on different developmental stages of $F$. enigmaticus.

Thus, in order to pursuing the use of sponge's extracts as natural-based antifouling booster compounds confirming their effectiveness, further evaluations appear warranted. Finally, further assays are mandatory to chemically characterize the extracts, to individuate those responsible for the observed toxicity and, ultimately, attempt their active use in new-generation antifouling paints.

\section{Declarations}

Ethics approval and consent to participate: All applicable international, national, and/or institutional guidelines for the care and use of animals were followed.

Consent for publication: Not applicable

Availability of data and materials: All data generated or analysed during this study are included in this published article [and its supplementary information files].

Competing interests: The authors declare that they have no known competing financial interests or personal relationships that could have appeared to influence the work reported in this paper.

Funding: Alessia Cuccaro benefited from a PhD grant (PD/BD/150609/2020) given by the National Funds through the Portuguese Science Foundation (Fundação para a Ciência e a Tecnologia, FCT). Lucia De Marchi benefited from a grant given by European Funds for Regional Development through the Interreg Marittimo-IT FR-Maritime 2014/2020 Project “QUALIPORTI".

Authors' contributions: Carlo Pretti and Fabio Bulleri supervised the project, Lucia De Marchi wrote the original manuscript draft with support from Matteo Oliva, Alessia Cuccaro, Fabio Bulleri and Carlo Pretti, Gianfranca Monni and Lucia De Marchi performed laboratory experiments related to biomarkers analyses, Lucia De Marchi, Matteo Oliva and Alessia Cuccaro performed laboratory experiments related to ecotoxicological bioassay, Michele Magri, Lucia De Marchi and Fabio Bulleri performed field and underwater work, Lucia De Marchi and Federica Tardelli performed all chemical analyses, Lucia De Marchi, Matteo Oliva and Alessia Cuccaro verified the analytical methods, Lucia De Marchi, Carlo Pretti, Alessia Cuccaro, Matteo Oliva, Federica Tardelli, Gianfranca Monni, Michele Magri, Fabio Bulleri contributed to the interpretation of results, Lucia De Marchi, Matteo Oliva, Alessia Cuccaro, Carlo Pretti, Fabio Bulleri reviewed and edited the final version of manuscript, all authors discussed results and contributed to the final manuscript.

\section{Acknowledgements}

Alessia Cuccaro benefited from a PhD grant (PD/BD/150609/2020) given by the National Funds through the Portuguese Science Foundation (Fundação para a Ciência e a Tecnologia, FCT).

Lucia De Marchi benefited from a grant given by European Funds for Regional Development through the Interreg Marittimo-IT FR-Maritime 2014/2020 Project “QUALIPORTI”.

\section{References}

1. Abbas, M., Adil, M., Ehtisham-ul-Haque, S., Munir, B., Yameen, M., Ghaffar, A., Shar, G.A., Thir, M.A., Iqbal, M. (2018). Vibrio fischeri bioluminescence inhibition assay for ecotoxicity assessment: a review. Sci. Total Environ. 626, 1295-1309. https://doi.org/10.1016/j.scitotenv.2018.01.066.

2. Agarwal, A., Saleh, R.A., Bedaiwy, M.A. (2003). Role of reactive oxygen species in the pathophysiology of human reproduction. Fertil. Steril. 79, 829-43. https://doi.org/10.1016/s0015-0282(02)04948-8.

3. Batista, D., Tellini, K., Nudi, A.H., Massone, T.P., Scofield, A.D.L., de LR Wagener, A. (2013). Marine sponges as bioindicators of oil and combustion derived PAH in coastal waters. Mar. Environ. Res. 92, 234-243. https://doi.org/10.1016/j.marenvres.2013.09.022.

4. Batista-Andrade, J.A., Caldas, S.S., Batista, R.M., Castro, I.B., Fillmann, G., Primel, E.G. (2018). From TBT to booster biocides: levels and impacts of antifouling along coastal areas of Panama. Environ. Pollut. 234, 243-252. https://doi.org/10.1016/j.envpol.2017.11.063.

5. Beedessee, G., Ramanjooloo, A., Surnam-Boodhun, R., Van Soest, R.W., Marie, D.E. (2013). Acetylcholinesterase-inhibitory activities of the extracts from sponges collected in Mauritius waters. Chem. Biodivers. 10(3), 442-451. https://doi.org/10.1002/cbdv.201200343.

6. Bell, J.J. (2008). The functional roles of marine sponges. Estuar. Coast. Shelf Sci. 79(3), 341-353. https://doi.org/10.1016/j.ecss.2008.05.002.

7. Cebrian, E., Uriz, M.J., Turon, X. (2007) Sponges as biomonitors of heavy metals in spatial and temporal surveys in northwestern mediterranean: multispecies comparison. Environ. Toxicol. Chem. 26(11), 2430-2439. https://doi.org/10.1897/07-292.1.

8. Châtel, A., Talarmin, H., Hamer, B., Schröder, H.C., Müller, W.E., Dorange, G. (2011). MAP kinase cell signaling pathway as biomarker of environmental pollution in the sponge Suberites domuncula. Ecotoxicology. 20(8), 1727-1740. https://doi.org/10.1007/s10646-011-0706-1. 
9. Cimino G., De Stefano S., Fattoruso E. and Minale L. (1972), Ircinin-1 and-2, linear sesterterpenes from the marine sponge Ircinia oros. Tetrahedron. 28, 333-341. https://doi.org/10.1016/0040-4020(72)80140-6.

10. Costa, G., Bertolino, M., Pinna, S., Bonaviri, C., Padiglia, A., Zinni, M., Pronzato, R., Manconi, R. (2018). Mediterranean sponges from shallow subtidal rocky reefs: Cystoseira canopy vs barren grounds. Estuar. Coast. Shelf Sci. 207, 293-302. https://doi.org/10.1016/j.ecss.2018.04.002.

11. Cuccaro, A., De Marchi, L., Oliva, M., Sanches, M. V., Freitas, R., Casu, V., Monni, G., Miragliotta, V., Pretti, C. (2020). Sperm quality assessment in Ficopomatus enigmaticus (Fauvel, 1923): Effects of selected organic and inorganic chemicals across salinity levels Ecotoxicol. Environ. Saf. 207, 111219. https://doi.org/10.1016/j.ecoenv.2020.111219.

12. Du Plessis, S.S., McAllister, D.A., Luu, A., Savia, J., Agarwal, A., Lampiao, F. (2010). Effects of $\mathrm{H}_{2} \mathrm{O}_{2}$ exposure on human sperm motility parameters, reactive oxygen species levels and nitric oxide levels. Andrologia. 42, 206-10. https://doi.org/10.1111/j.1439-0272.2009.00980.x.

13. Duque, C., Bonilla, A., Bautista, E., Zea, S. (2001). Exudation of low molecular weight compounds (thiobismethane, methyl isocyanide, and methyl isothiocyanate) as a possible chemical defense mechanism in the marine sponge Ircinia felix. Biochem. Syst. Ecol. $29(5), 459-467$. https://doi.org/10.1016/s0305-1978(00)00081-8.

14. Efremova, S.M., Margulis, B.A., Guzhova, I.V., Itskovich, V.B., Lauenroth, S., Müller, W.E., Schröder, H.C. (2002) Heat shock protein Hsp70 expression and DNA damage in Baikalian sponges exposed to model pollutants and wastewater from Baikalsk Pulp and Paper Plant. Aquat. Toxicol. 57, 267-280. https://doi.org/10.1016/s0166-445x(01)00209-0.

15. Eguía, E., Trueba, A. (2007). Application of marine biotechnology in the production of natural biocides for testing on environmentally innocuous antifouling coatings. J. Coat. Technol. Res. 4, 191-202. https://doi.org/10.1007/s11998-007-9080-6.

16. Ellman, G.L. Courtney, K.D., Andres, V., Featherstone, R.M. (1961). A New and rapid colorimetric determination of acetylcholinesterase activity. Biochem. Pharmacol. 7, 88-95. https://doi.org/10.1016/0006-2952(61)90145-9.

17. Elsayed, M., El-Sherry, T. M., Abdelgawad, M. (2015). Development of computer-assisted sperm analysis plugin for analyzing sperm motion in microfluidic environments using Image-J. Theriogenology, 84(8), 1367-1377. https://doi.org/10.1016/j.theriogenology.2015.07.021.

18. Finney, D.J. (1971). Probit Analysis, third ed. Cambridge University Press, London.

19. Ford WC. (2004). Regulation of sperm function by reactive oxygen species. Hum. Reprod. Update. 10, $387-99$. https://doi.org/10.1093/humupd/dmh034.

20. Garaventa, F., Piazza, V., Zovko, A., Turk, T., Chelossi, E., Falugi, C., Aluigi, M.G., Angelini, G., Trombino, S., Gallus, L., Ferrando, S., Albini, A., Paleari, L., Sepčič, K., Faimali, M. (2010). Multiple functions of the cholinesterase inhibiting polyalkylpyridinium salts extracted from the marine sponge, Haliclona sarai. WSEAS Trans. Biol. Biomed. 7(3), 103-113.

21. Gentric, C., Rehel, K., Dufour, A., Sauleau, P. (2016). Bioaccumulation of metallic trace elements and organic pollutants in marine sponges from the South Brittany Coast, France. J. Environ. Sci. Health A Tox. Hazard. Subst. Environ. Eng. 51(3), $213-219$. https://doi.org/10.1080/10934529.2015.1094327.

22. Hasan, C.K., Turner, A., Readman, J., Frickers, T. (2014). Environmental Risks Associated with Booster Biocides Leaching from Spent Anti-Fouling Paint Particles in Coastal Environments. Water Environ. Res. 86(12), 2330-2337. https://doi.org/10.2175/106143014X14062131178835.

23. Hasson, D., Shemer, H., Sher, A. (2011). State of the art of friendly “green” scale control inhibitors: a review article. Ind. Eng. Chem. Res. 50(12), 7601-7607. https://doi.org/10.1021/ie200370v.

24. Helber, S.B., Hoeijmakers, D.J., Muhando, C.A., Rohde, S., Schupp, P.J. (2018). Sponge chemical defenses are a possible mechanism for increasing sponge abundance on reefs in Zanzibar. PloS one. 13(6), e0197617. https://doi.org/10.1371/journal.pone.0197617.

25. Hellio, C., Tsoukatou, M., Marechal, J.P., Aldred, N., Beaupoil, C., Clare, A.S., Vagias, C., Roussis, V. (2005). Inhibitory effects of Mediterranean sponge extracts and metabolites on larval settlement of the barnacle Balanus amphitrite. Mar. Biotechnol. 7(4), $297-305$. https://doi.org/10.1007/s10126-004-3150-x.

26. Herath, H.M.P., Preston, S., Jabbar, A., Garcia-Bustos, J., Taki, A. C., Addison, R. S., Gasser, R.B. (2019). Identification of fromiamycalin and halaminol A from Australian marine sponge extracts with anthelmintic activity against Haemonchus contortus. Mar. Drugs. 17(11), 598. https://doi.org/10.3390/md17110598.

27. Herrero, M.B., de Lamirande, E., Gagnon, C. (1999). Nitric oxide regulates human sperm capacitation and protein tyrosine phosphorylation in vitro. Biol. Reprod. 61, 575-81. https://doi.org/10.1095/biolreprod61.3.575.

28. Ledda, F.D., Pronzato, R., Manconi, R. (2014). Mariculture for bacterial and organic waste removal: a field study of sponge filtering activity in experimental farming. Aquac. Res. 45(8), 1389-1401. https://doi.org/10.1111/are.12084.

29. Lowry, O.H., Rosebrough, N.J., Farr, A.L., Randall, R.J. (1951). Protein measurement with the folin phenol reagent. J. Biol. Chem. 1951, 193, 265275.

30. Marques, D., Almeida, M., Xavier, J., Humanes, M. (2007). Biomarkers in marine sponges: acetylcholinesterase in the sponge Cliona celata. Porifera research: biodiversity, innovation and sustainability. Museu Nacional Rio de Janeiro, Rio de Janeiro, $427-432$.

31. Mihopoulos, N., Vagias, C., Chinou, I., Roussakis, C., Scoullos, M., Harvala, C., Roussis V. (1999). Anti-bacterial and cytotoxic natural and synthetisized hydroquinones from sponge Ircinia spinolusa. Z. Naturforsch C. https://doi.org/10.1515/znc-1999-5-618. 
32. Mohammed, A. (2013). Why are early life stages of aquatic organisms more sensitive to toxicants than adults? New insights into toxicity and drug testing, 49-62.

33. Mohammed, A., Halfhide, T., Elias-Samlalsingh, N. (2009). Comparative sensitivity of six toxicants of two life stages of the tropical mysid, Metamysidopsis insularis. Environ. Toxicol. Chem. 97(7), 1331-1337.

34. Mol, V.L., Raveendran, T.V., Parameswaran, P.S. (2009). Antifouling activity exhibited by secondary metabolites of the marine sponge, Haliclona exigua (Kirkpatrick). Int. Biodeter. Biodegr. 63(1), 67-72.

35. Müller, W.E.G., Müller, I. (1998). Sponge cells and tissue as biological monitors of aquatic pollution. In: Wells PG, Lee K, Blase C (eds) Microscale aquatic toxicology-advances, techniques and practice. CRC Lewis Publishers, Boca Raton.

36. O'Flaherty, C.M., Beorlegui, N.B., Beconi, M.T. (1999). Reactive oxygen species requirements for bovine sperm capacitation and acrosome reaction. Theriogenology. 52, 289-301. https://doi.org/10.1016/S0093-691X(99)00129-6.

37. Oliva, M., De Marchi, L., Vieira Sanches, M., Pires, A., Cuccaro, A., Baratti, M., Chiellini, F., Morelli, A., Freitas, R., Pretti, C. (2020). Atlantic and Mediterranean populations of the widespread serpulid Ficopomatus enigmaticus: Developmental responses to carbon nanotubes. Mar. Pollut. Bull. 156, 111-265. https://doi.org/10.1016/j.marpolbul.2020.111265.

38. Oliva, M., Manzini, C., Bontà Pittaluga, G., Kozinkova, L., De Marchi, L., Freitas, R., Fabi, G., Pretti, C. (2019). Ficopomatus enigmaticus larval development assay: An application for toxicity assessment of marine sediments. Mar. Pollut. Bull. 139, 189-196. https://doi.org/10.1016/j.marpolbul.2018.12.033.

39. Oliva, M., Mennillo, E., Barbaglia, M., Monni, G., Tardelli, F., Casu, V., Pretti, C. (2018). The serpulid Ficopomatus enigmaticus (Fauvel, 1923) as candidate organisms for ecotoxicological assays in brackish and marine waters. Ecotoxicol. Environ. Saf. 148, 1096-103. https://doi.org/10.1016/j.ecoenv.2015.10.006.

40. Pawlik, J.R. (2012). Antipredatory defensive roles of natural products from marine invertebrates. Handbook of marine natural products, $677-710$.

41. Pawlik, J. R., Steindler, L., Henkel, T.P., Beer, S., Ilan, M. (2007). Chemical warfare on coral reefs: sponge metabolites differentially affect coral symbiosis in situ. Limnol. Oceanogr. Lett. 52(2), 907-911. https://doi.org/10.4319/lo.2007.52.2.0907.

42. Perez T., Sarrazin L., Rebouillon P., Vacelet J. (2002) First evidences of surfactant biodegradation by marine sponges (Porifera): an experimental study with a linear alkylbenzenesulfonate. Hydrobiologia. 489, 225- 233. https://doi.org/10.1023/A:1023217218585.

43. Perez T., Wafo E., Fourt M., Vacelet, J. (2003) Marine sponges as biomonitor of polychlorobiphenyl contamination: concentration and fate of 24 congeners. Environ. Sci. Technol. 37, 2152-2158. https://doi.org/10.1021/es026234v.

44. Rao, J.V., Kavitha, P., Reddy, N.C., Rao, T.G. (2006) Petrosia testudinaria as a biomarker for metal contamination at Gulf of Mannar, southeast coast of India. Chemosphere. 65(4), 634-638. https://doi.org/10.1016/j.chemosphere.2006.01.072.

45. Reiswig, H.M. (1974). Water transport, respiration and energetics of three tropical marine sponges. J. Exp. Mar. Bio. Ecol. 14, $231-49$.

46. Riesgo, A., Pérez-Portela, R., Pita, L., Blasco, G., Erwin, P. M., López-Legentil, S. (2016). Population structure and connectivity in the Mediterranean sponge Ircinia fasciculata are affected by mass mortalities and hybridization. Heredity. 117(6), 427-439. https://doi.org/10.1038/hdy.2016.41.

47. Sánchez-Lozano, I., Hernández-Guerrero, C.J., Muñoz-Ochoa, M., Hellio, C. (2019). Biomimetic approaches for the development of new antifouling solutions: Study of incorporation of macroalgae and sponge extracts for the development of new environmentally-friendly coatings. Int. J. Mol. Sci. 20(19), 4863. https://doi.org/10.3390/ijms20194863.

48. Santillo, D., Johnston, P., Langston, W. J. (2001). Tributyltin (TBT) antifoulants: a tale of ships, snails and imposex, chapter 13 in Late Lessons from Early warnings.

49. Su, L. J., Zhang, J. H., Gomez, H., Murugan, R., Hong, X., Xu, D., Jiang, F., Peng, Z.Y. (2019). Reactive oxygen species-induced lipid peroxidation in apoptosis, autophagy, and ferroptosis. Oxid. Med. Cell. Longev. 2019, 5080843. https://doi.org/10.1155/2019/5080843.

50. Takur N.,Anil A. (2000), Antibacterial activity of the sponge Ircinia ramosa: importance of its surface-associated bacteria. J. Chem. Ecol. 26, 57D71. https://doi.org/10.1023/A:1005485310488.

51. Thakur, N. L., Singh, A. (2016). Chemical ecology of marine sponges. In Marine Sponges: Chemicobiological and Biomedical Applications (pp. 3752). Springer, New Delhi.

52. Thakur, N.L., Anil, A.C., Müller, W.E. (2004). Culturable epibacteria of the marine sponge Ircinia fusca: temporal variations and their possible role in the epibacterial defense of the host. Aquat. Microb. Ecol. 37(3), 295-304. https://doi.org/10.3354/ame037295.

53. Thomas, K.V., Brooks, S. (2010). The environmental fate and effects of antifouling paint biocides. Biofouling, 26(1), 73-88. https://doi.org/10.1080/08927010903216564.

54. Tsoukatou, M., Hellio, C., Vagias, C., Harvala, C., Roussis, V. (2002). Chemical defense and antifouling activity of three Mediterranean sponges of the genus Ircinia. Z. Naturforsch. C. J. Biosci. 57(1-2), 161-171. https://doi.org/10.1515/znc-2002-1-227.

55. Vigneron, A., Head, I.M., Tsesmetzis, N. (2018). Damage to o shore production facilities by corrosive microbial biofilms. Appl. Microbiol. Biotech. $102,2525-2533$.

56. Wessler, I., Kirkpatrick, C.J. (2008). Acetylcholine beyond neurons: the non-neuronal cholinergic system in humans. Br. J. Pharmacol. 154(8), 1558-1571. https://doi.org/10.1038/bjp.2008.185.

57. Wulff, J.L. (2006). Ecological interactions of marine sponges. Can. J. Zool. 84, 146-166. https://doi.org/10.1139/z06-019.

Page 9/17 
58. Zahn, R.K., Zahn, G., Müller, W.E.G., Müller, I., Beyer, R., Müller-Berger, U., Britvić, S. (1977). Consequences of detergent pollution of the sea: effects on regenerating sponge cubes of Geodia cydonium. Sci. Total Environ. 8(2), 109-151. https://doi.org/10.1016/0048-9697(77)90072-9.

\section{Tables}

Table 1. Growth inhibition in Phaeodactylum tricornutum. Results are expressed as $\mathrm{EC}_{10 / 20 / 50}(\mu \mathrm{g} / \mathrm{mL})$ together with $95 \%$ confidence limits (C.L.). ECs were obtained by a linear interpolation method. n.c: not calculable.

\begin{tabular}{|lllllll|}
\hline Extracts & $\mathrm{EC}_{10}$ & C.L. (95\%) & $\mathrm{EC}_{20}$ & C.L. (95\%) & $\mathrm{EC}_{50}$ & C.L. (95\%) \\
\hline DA & 27.71 & $20.76-28.68$ & 31.53 & $28.82-32.35$ & 42.99 & $41.84-43.41$ \\
\hline WA & 8.22 & $6.95-10.0$ & 16.85 & $10.33-20.75$ & 38.26 & $36.86-40.38$ \\
\hline WH & 5.29 & $5.04-5.48$ & 6.79 & $6.55-6.95$ & 12.17 & $11.79-12.50$ \\
\hline DH & 0.79 & $0.46-1.07$ & 6.09 & $4.08-5.27$ & 9.70 & $9.02-10.56$ \\
\hline
\end{tabular}

DA: dry sponges portioned with AcOEt; WA: wet sponges portioned with AcOEt.; WH: wet sponges portioned with hexane; DH: dry sponges portioned with hexane

Table 2. Sperm motion assay in Ficopomatus enigmaticus. Results of sperm cells' motion in microfluidic environments. VCL, curvilinear velocity; VAP, average path velocity; VSL, straight line velocity; LIN, Linearity, VSL/VAP; WOB, Wobble (VAP/VCL), a measure of sperm head side to side movement; PROG, Progression (distance sperm traveled on VAP path); BCF, Beat cross frequency. The analysis was performed for all tested extracts (DH, DA, $\mathrm{WH}, \mathrm{WA}$ ) at the concentrations of $0.5 ; 1.0 ; 2.5 ; 5.0$ and $10.0 \mu \mathrm{g} / \mathrm{mL}$. 


\begin{tabular}{|c|c|c|c|c|c|c|c|c|}
\hline Extracts & $\begin{array}{l}\text { Concentrations } \\
(\mu \mathrm{g} / \mathrm{mL})\end{array}$ & $\operatorname{VCL}(\mu \mathrm{m} / \mathrm{s})$ & $\operatorname{VAP}(\mu \mathrm{m} / \mathrm{s})$ & VSL $(\mu \mathrm{m} / \mathrm{s})$ & LIN & WOB & PROG $(\mu \mathrm{m})$ & $\mathrm{BCF}(\mathrm{Hz})$ \\
\hline \multirow[t]{6}{*}{ DA } & 0.0 & $350.16 \pm 167.80$ & $167.35 \pm 124.63$ & $392.37 \pm 61.18$ & $1.82 \pm 1.40$ & $0.44 \pm 0.14$ & $3044.35 \pm 1914.31$ & $25.31 \pm 6.69$ \\
\hline & 0.5 & $243.04 \pm 6.04$ & $162.85 \pm 93.78$ & $149.47 \pm 20.46$ & $0.89 \pm 0.11$ & $0.68 \pm 0.40$ & $7175.25 \pm 3401.73$ & $21.27 \pm 0.43$ \\
\hline & 1.0 & $161.69 \pm 12.97$ & $76.63 \pm 0.89$ & $64.76 \pm 0.17$ & $0.85 \pm 0.01$ & $0.48 \pm 0.03$ & $2279.84 \pm 621.49$ & $30.20 \pm 3.33$ \\
\hline & 2.5 & $192.46 \pm 31.07$ & $143.97 \pm 52.51$ & $133.81 \pm 49.73$ & $0.93 \pm 0.01$ & $0.74 \pm 0.15$ & $4052.36 \pm 314.42$ & $30.49 \pm 4.67$ \\
\hline & 5.0 & $169.21 \pm 45.43$ & $106.50 \pm 60.98$ & $90.28 \pm 64.05$ & $0.81 \pm 0.14$ & $0.60 \pm 0.20$ & $2530.00 \pm 370.71$ & $32.54 \pm 7.43$ \\
\hline & 10 & $199.54 \pm 53.54$ & $63.49 \pm 20.43$ & $67.41 \pm 39.03$ & $1.02 \pm 0.29$ & $0.32 \pm 0.02$ & $1498.53 \pm 161.99$ & $32.49 \pm 2.11$ \\
\hline \multirow[t]{6}{*}{ WA } & 0.0 & $281.25 \pm 63.57$ & $122.73 \pm 61.81$ & $316.94 \pm 63.48$ & $2.10 \pm 1.90$ & $0.42 \pm 0.12$ & $2905.61 \pm 1295.90$ & $32.60 \pm 2.91$ \\
\hline & 0.5 & $467.98 \pm 40.16$ & $236.77 \pm 26.37$ & $251.72 \pm 94.61$ & $1.05 \pm 0.28$ & $0.51 \pm 0.10$ & $2122.46 \pm 70.16$ & $21.35 \pm 0.48$ \\
\hline & 1.0 & $286.33 \pm 91.67$ & $94.37 \pm 23.79$ & $141.67 \pm 122.29$ & $1.38 \pm 0.95$ & $0.33 \pm 0.02$ & $2026.11 \pm 483.93$ & $28.84 \pm 2.76$ \\
\hline & 2.5 & $301.23 \pm 25.67$ & $103.28 \pm 12.28$ & $103.61 \pm 17.09$ & $1.02 \pm 0.29$ & $0.35 \pm 0.07$ & $1651.09 \pm 344.56$ & $29.42 \pm 1.52$ \\
\hline & 5.0 & $463.35 \pm 7.11$ & $224.15 \pm 21.68$ & $162.49 \pm 19.24$ & $0.72 \pm 0.02$ & $0.48 \pm 0.04$ & $1945.81 \pm 716.41$ & $25.61 \pm 1.89$ \\
\hline & 10 & $252.62 \pm 11.11$ & $86.16 \pm 033$ & $117.36 \pm 31.68$ & $1.36 \pm 0.36$ & $0.34 \pm 0.02$ & $2133.28 \pm 416.21$ & $30.64 \pm 2.08$ \\
\hline \multirow[t]{6}{*}{ WH } & 0.0 & $219.65 \pm 46.48$ & $93.15 \pm 27.88$ & $81.29 \pm 31.66$ & $0.86 \pm 0.07$ & $0.42 \pm 0.08$ & $1920.20 \pm 822.18$ & $28.80 \pm 6.10$ \\
\hline & 0.5 & $238.51 \pm 37.23$ & $81.01 \pm 0.73$ & $101.94 \pm 42.96$ & $1.24 \pm 0.52$ & $0.35 \pm 0.06$ & $1408.17 \pm 209.45$ & $30.25 \pm 0.64$ \\
\hline & 1.0 & $258.88 \pm 54.05$ & $103.12 \pm 14.43$ & $157.05 \pm 115.20$ & $1.44 \pm 0.88$ & $0.41 \pm 0.09$ & $1963.98 \pm 789.30$ & $29.65 \pm 1.79$ \\
\hline & 2.5 & $202.02 \pm 11.41$ & $58.61 \pm 2.13$ & $84.81 \pm 26.05$ & $1.44 \pm 0.39$ & $0.29 \pm 0.01$ & $519.85 \pm 34.78$ & $33.18 \pm 0.88$ \\
\hline & 5.0 & $252.76 \pm 37.78$ & $137.72 \pm 60.67$ & $149.32 \pm 48.50$ & $1.11 \pm 0.14$ & $0.53 \pm 0.16$ & $4542.51 \pm 428.38$ & $30.87 \pm 0.50$ \\
\hline & 10 & $231.09 \pm 22.14$ & $85.77 \pm 5.81$ & $98.38 \pm 49.70$ & $1.11 \pm 0.50$ & $0.37 \pm 0.06$ & $1143.77 \pm 209.66$ & $30.51 \pm 0.56$ \\
\hline \multirow[t]{6}{*}{ DH } & 0.0 & $257.97 \pm 11.04$ & $105.07 \pm 68.22$ & $241.88 \pm 40.66$ & $1.97 \pm 1.01$ & $0.39 \pm 0.10$ & $1134.51 \pm 84.23$ & $29.41 \pm 0.56$ \\
\hline & 0.5 & $296.99 \pm 96.65$ & $89.47 \pm 22.22$ & $164.48 \pm 77.92$ & $1.79 \pm 0.43$ & $0.31 \pm 0.02$ & $1755.16 \pm 3.94$ & $32.62 \pm 4.38$ \\
\hline & 1.0 & $299.53 \pm 29.37$ & $93.75 \pm 9.68$ & $249.08 \pm 27.49$ & $2.80 \pm 2.02$ & $0.31 \pm 0.06$ & $1364.85 \pm 592.02$ & $31.79 \pm 0.69$ \\
\hline & 2.5 & $569.60 \pm 190.40$ & $375.11 \pm 293.89$ & $286.85 \pm 126.22$ & $0.76 \pm 0.02$ & $0.61 \pm 0.31$ & $3119.25 \pm 435.20$ & $19.22 \pm 0.45$ \\
\hline & 5.0 & $383.63 \pm 26.96$ & $106.07 \pm 4.43$ & $83.82 \pm 14.56$ & $0.79 \pm 0.10$ & $0.28 \pm 0.01$ & $1088.14 \pm 16.47$ & $28.95 \pm 0.04$ \\
\hline & 10 & $255.88 \pm 115.38$ & $59.02 \pm 15.20$ & $111.40 \pm 68.00$ & $2.11 \pm 1.69$ & $0.24 \pm 1.69$ & $1126.10 \pm 36.70$ & $31.05 \pm 3.03$ \\
\hline
\end{tabular}

DA: dry sponges portioned with AcOEt; WA: wet sponges portioned with AcOEt.; WH: wet sponges portioned with hexane; DH: dry sponges portioned with hexane

Table 3. Motility assay in Ficopomatus enigmaticus: Two-way ANOVA output for motility assay performed for all tested extracts (DH, DA, WH, WA) at the respective concentrations $(0.5 ; 1.0 ; 2.5 ; 5.0$ and $10.0 \mu \mathrm{g} / \mathrm{mL})$. The analysis was followed by a post-test (Bonferroni) for multiple comparison. Source of variations; Df; F; $p<0.001(*)$.

\begin{tabular}{|llll|}
\hline Motility & & & \\
\hline Source of variation & $\%$ tot variation & Df & F \\
\hline Interaction & $15.24^{*}$ & 15 & 108200 \\
\hline Concentrations & $69.68^{*}$ & 5 & 1475000 \\
\hline Extracts & 14.98 & 3 & 528600 \\
\hline Residual & & 48 & \\
\hline
\end{tabular}

Table 4. Ficopomatus enigmaticus: Vitality and Cellular damage: Two-way ANOVA output for sperm quality biomarkers (intracellular reactive oxygen species (ROS), lipid peroxidation (LPO), sperm viability (MTT) and DNA damage) performed for all tested extracts (DH, DA, WH, WA) at the respective 
concentrations $(0.05 ; 0.1 ; 0.25 ; 0.5 ; 1.0 ; 2.5 ; 5.0$ and $10.0 \mu \mathrm{g} / \mathrm{mL}$ ). The analysis was followed by a post-test (Bonferroni) for multiple comparison. Source of variations; Df; F; $p<0.001(*)$.

\begin{tabular}{|c|c|c|c|}
\hline \multicolumn{4}{|l|}{ ROS } \\
\hline Source of variation & $\%$ tot variation & Df & $\mathrm{F}$ \\
\hline Interaction & $50.67 *$ & 24 & 40.88 \\
\hline Concentrations & $41.61 *$ & 8 & 100.7 \\
\hline Extracts & 3.99 & 3 & 25.78 \\
\hline Residual & & 72 & \\
\hline \multicolumn{4}{|l|}{ LPO } \\
\hline Source of variation & $\%$ tot variation & Df & $\mathrm{F}$ \\
\hline Interaction & $55.35^{*}$ & 24 & 26.10 \\
\hline Concentrations & $35.44^{*}$ & 8 & 50.14 \\
\hline Extracts & 2.85 & 3 & 10.74 \\
\hline Residual & & 72 & \\
\hline \multicolumn{4}{|l|}{ MTT } \\
\hline Source of variation & $\%$ tot variation & Df & $\mathrm{F}$ \\
\hline Interaction & $55.23^{*}$ & 24 & 26.15 \\
\hline Concentrations & $36.29 *$ & 8 & 51.83 \\
\hline Extracts & 1.94 & 3 & 7.35 \\
\hline Residual & & 72 & \\
\hline \multicolumn{4}{|l|}{ DNA ssB } \\
\hline Source of variation & $\%$ tot variation & Df & $\mathrm{F}$ \\
\hline Interaction & $44.90 *$ & 24 & 9.27 \\
\hline Concentrations & $31.08 *$ & 8 & 19.26 \\
\hline Extracts & 9.50 & 3 & 15.69 \\
\hline Residual & & 72 & \\
\hline
\end{tabular}

Table 5. Larval development assay in Ficopomatus enigmaticus. Results are expressed as $\mathrm{EC}_{10 / 50}(\mu \mathrm{g} / \mathrm{mL})$ together with $95 \%$ confidence limits (C.L.). ECs were obtained by the use of a PROBIT model. n.c: not calculable because badly developed larvae were always under $20 \%$.

\begin{tabular}{|lllll|}
\hline Extracts & $\mathrm{EC}_{10}$ & C.L. (95\%) & $\mathrm{EC}_{50}$ & C.L. (95\%) \\
\hline DA & 3.66 & $2.58-4.40$ & 5.12 & $4.23-5.85$ \\
WA & 0.14 & - & 1.21 & - \\
\hline WH & 0.027 & $0.001-0.079$ & 0.89 & $0.46-3.28$ \\
DH & 0.002 & $0.00-0.021$ & 1.69 & $0.52-104.84$ \\
\hline
\end{tabular}

DA: dry sponges portioned with AcOEt; WA: wet sponges portioned with AcOEt.; WH: wet sponges portioned with hexane; DH: dry sponges portioned with hexane

Table 6. Larval development assay in Ficopomatus enigmaticus. Two-way ANOVA output for larval development assay performed for all tested extracts (DH, DA, WH, WA) at the respective concentrations $(0.05 ; 0.1 ; 0.25 ; 0.5 ; 1.0 ; 2.5 ; 5.0$ and $10.0 \mu \mathrm{g} / \mathrm{mL})$. The analysis was followed by a posttest (Bonferroni) for multiple comparison. Source of variations; Df; F; $p<0.001$ (*). 


\begin{tabular}{|llll|}
\hline Larval development & & & \\
\hline Source of variation & $\%$ tot variation & Df & F \\
\hline Interaction & $6.82^{*}$ & 33 & 46.11 \\
\hline Concentrations & $86.22 *$ & 11 & 1750 \\
\hline Extracts & 6.54 & 3 & 486.4 \\
\hline Residual & & 96 & \\
\hline
\end{tabular}

Table 7. AChE-inhibitory assay in Ficopomatus enigmaticus. Two-way ANOVA output for AChE-inhibitory assay performed for all tested extracts (DH, DA, WH, WA) at the respective concentrations $(5.0 ; 10.0 ; 25.0 ; 50.0$ and $100.0 \mu \mathrm{g} / \mathrm{mL})$. The analysis was followed by a post-test (Bonferroni) for multiple comparison. Source of variations; Df; F; $\left.p<0.001{ }^{*}\right)$.

\begin{tabular}{|llll|}
\hline AChE-inhibitory & & & \\
\hline Source of variation & $\%$ tot variation & Df & F \\
\hline Interaction & $1.13^{*}$ & 15 & 0.40 \\
\hline Concentrations & $89.39 *$ & 5 & 95.24 \\
\hline Extracts & 0.47 & 3 & 0.83 \\
\hline Residual & & 48 & \\
\hline
\end{tabular}

\section{Figures}




\section{Motility}

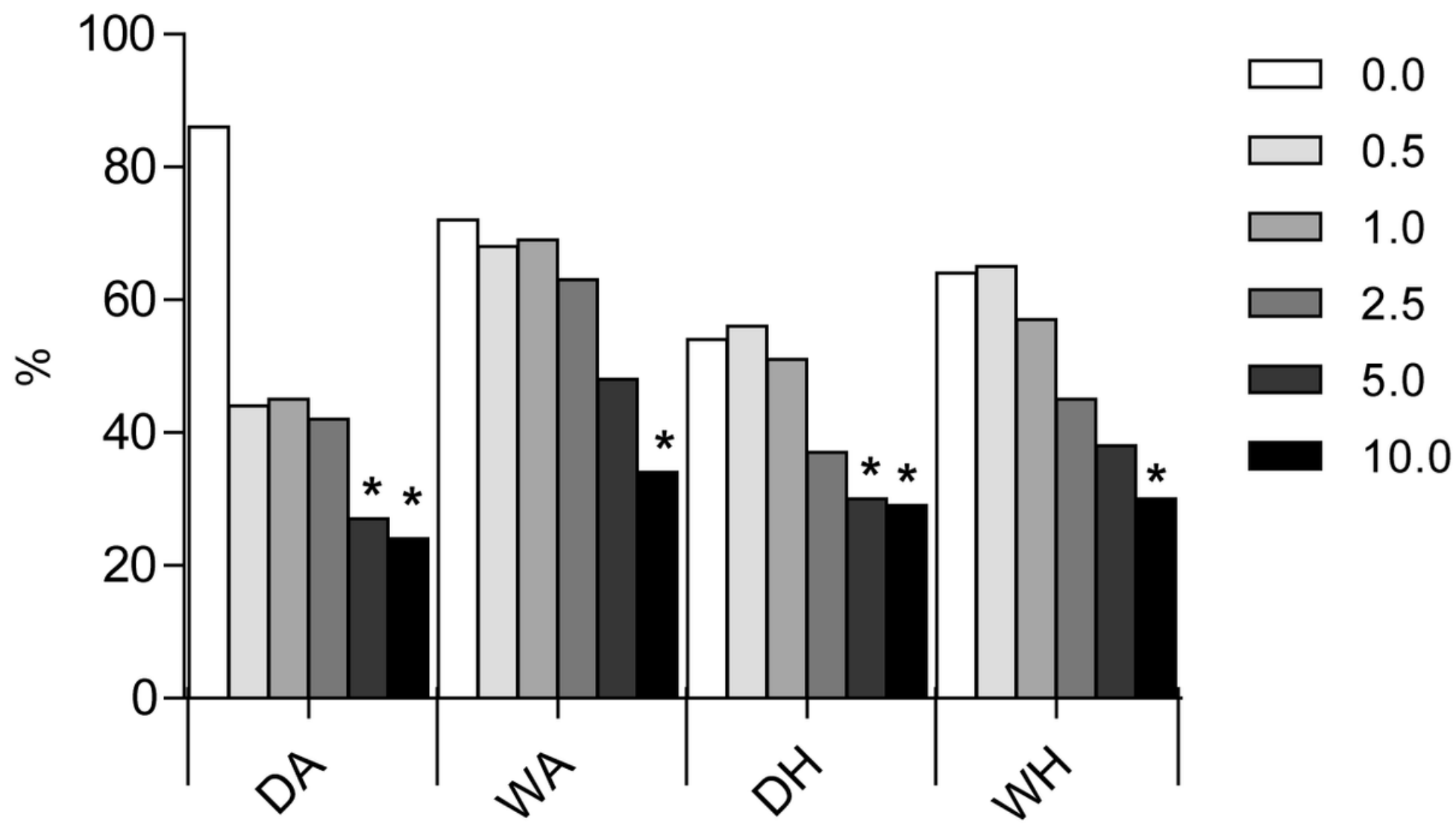

Extracts

Figure 1

Results of sperm motility of Ficopomatus enigmaticus when exposed to a range of concentrations $(0.0,0.5,1.0,2.5,5.0$ and $10.0 \mu \mathrm{g} / \mathrm{mL})$ of four different extracts (DA: dry sponges portioned with AcOEt, WA: wet sponges portioned with AcOEt., DH: dry sponges portioned with hexane, WH: wet sponges portioned with hexane). Results are expressed as a percentage. Mean \pm SD, $p<0.05(*), p<0.01(* *)$. 

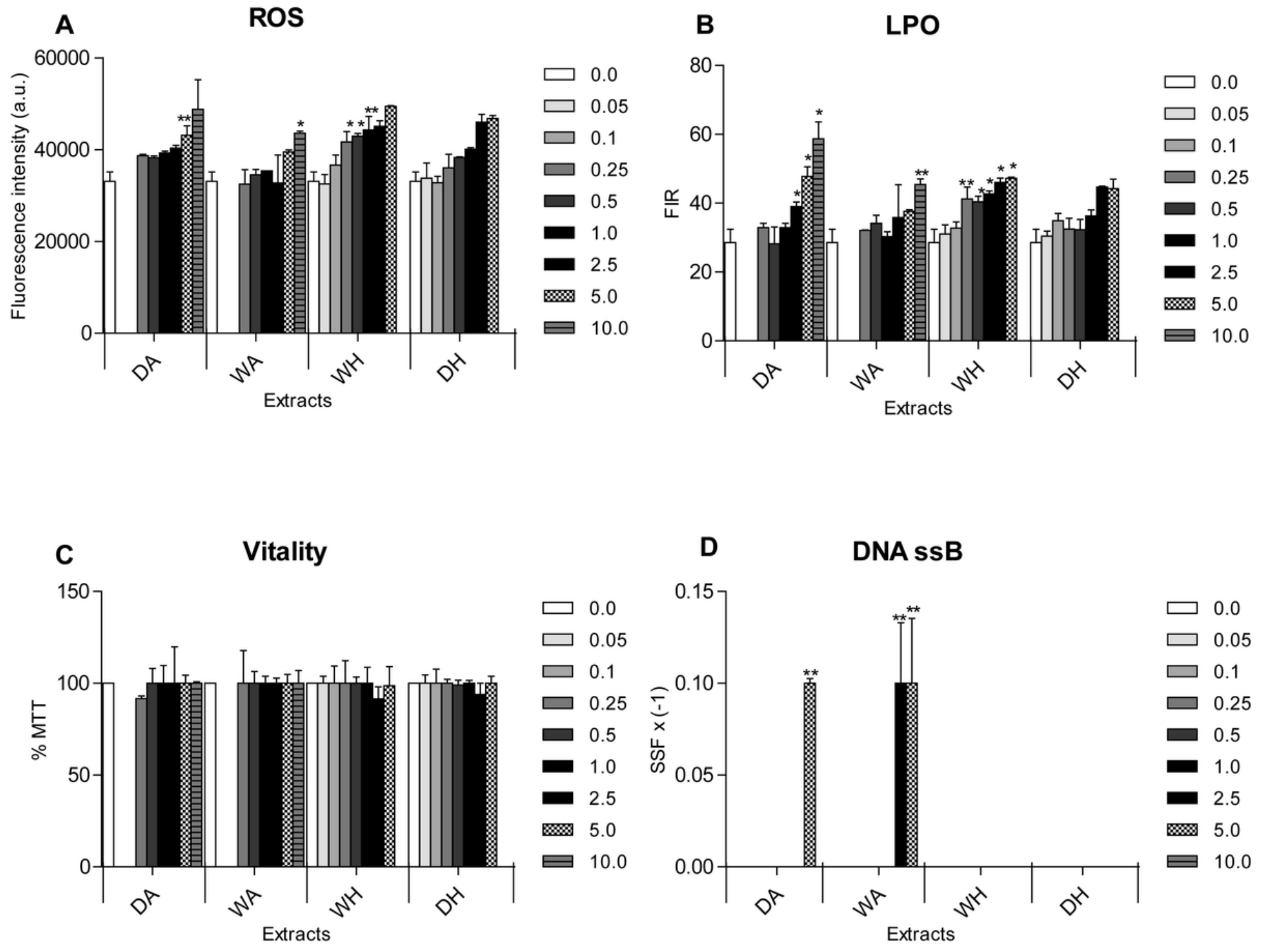

Figure 2

Results of spermiotoxicy tests on Ficopomatus enigmaticus when exposed to a range of concentrations $(0.0,0.05,0.1,0.25,0.5,1.0,2.5,5.0$ and 10.0 $\mu \mathrm{g} / \mathrm{mL}$ ) of four different extracts (DA: dry sponges portioned with AcOEt, WA: wet sponges portioned with AcOEt., DH: dry sponges portioned with hexane, WH: wet sponges portioned with hexane). A. Reactive oxygen species (ROS) levels were expressed as fluorescence intensity (a.u.), B. Lipid peroxidation (LPO) mean levels were expressed as fluorescence intensity ratio (FIR), C. Sperm vitality (MTT) mean values were expressed as percentage (\%) of MTT, D. Negative DNA Single-Strand-Break (DNA ssB) mean values were expressed as strand scission factors (SSF) $x(-1)$ and the control corresponded to the $x$-axis. Mean $\pm S D, p<0.05(*), p<0.01(* *)$. 


\section{Larval development}

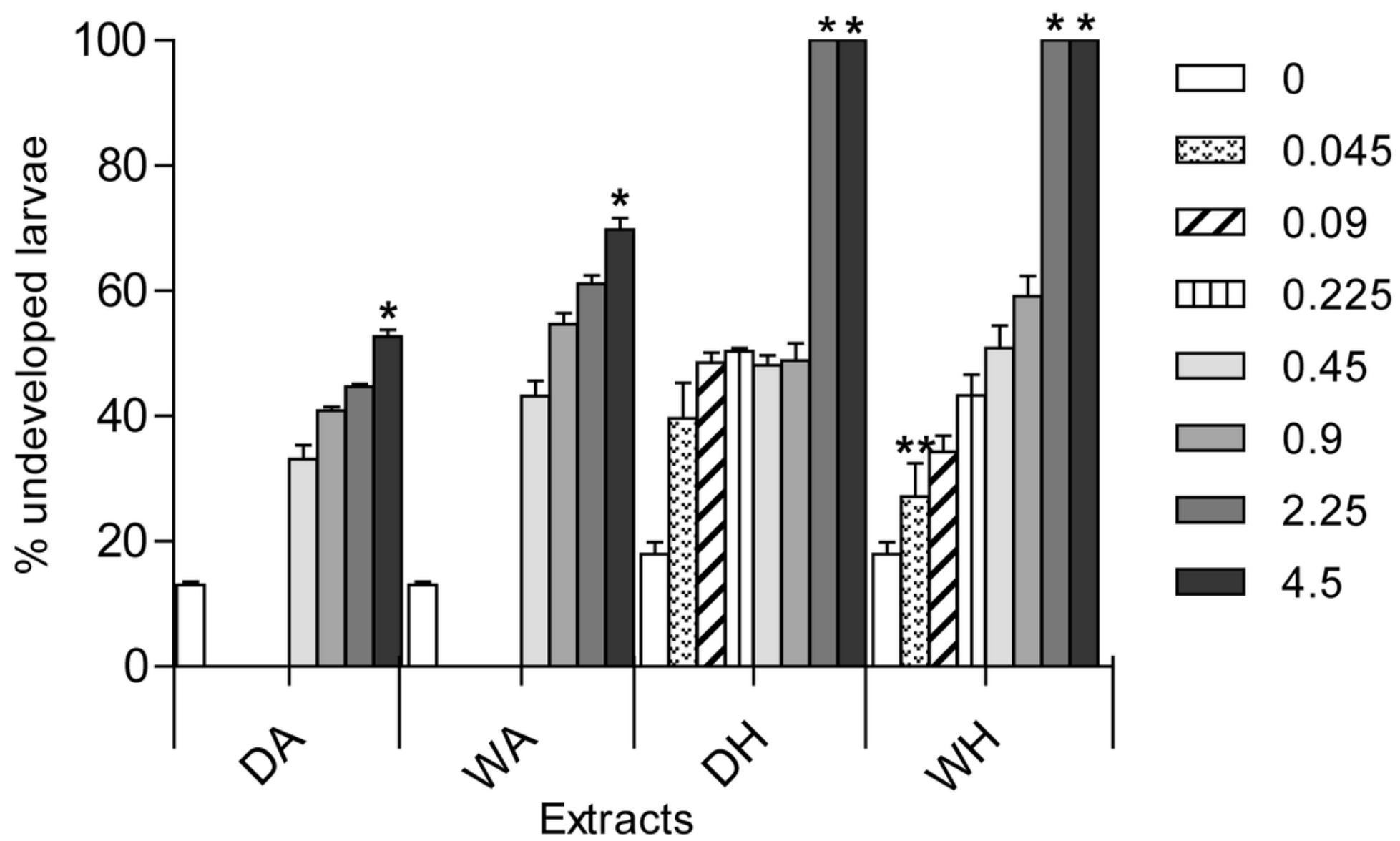

Figure 3

Results of Ficopomatus enigmaticus larval development assay when exposed to a nominal range of concentrations $(0.0,0.045,0.09,0.225,0.45,0.9$, 2.25 and $4.5 \mu \mathrm{g} / \mathrm{mL}$ ) of four different extracts (DA: dry sponges portioned with AcOEt, WA: wet sponges portioned with AcOEt., DH: dry sponges portioned with hexane, $\mathrm{WH}$ : wet sponges portioned with hexane). Results are expressed as percentage of undeveloped larvae. Mean $\pm \mathrm{SD}$, $\mathrm{p}<0.05$ ( ${ }^{2}$, $p<0.01(* *)$. 


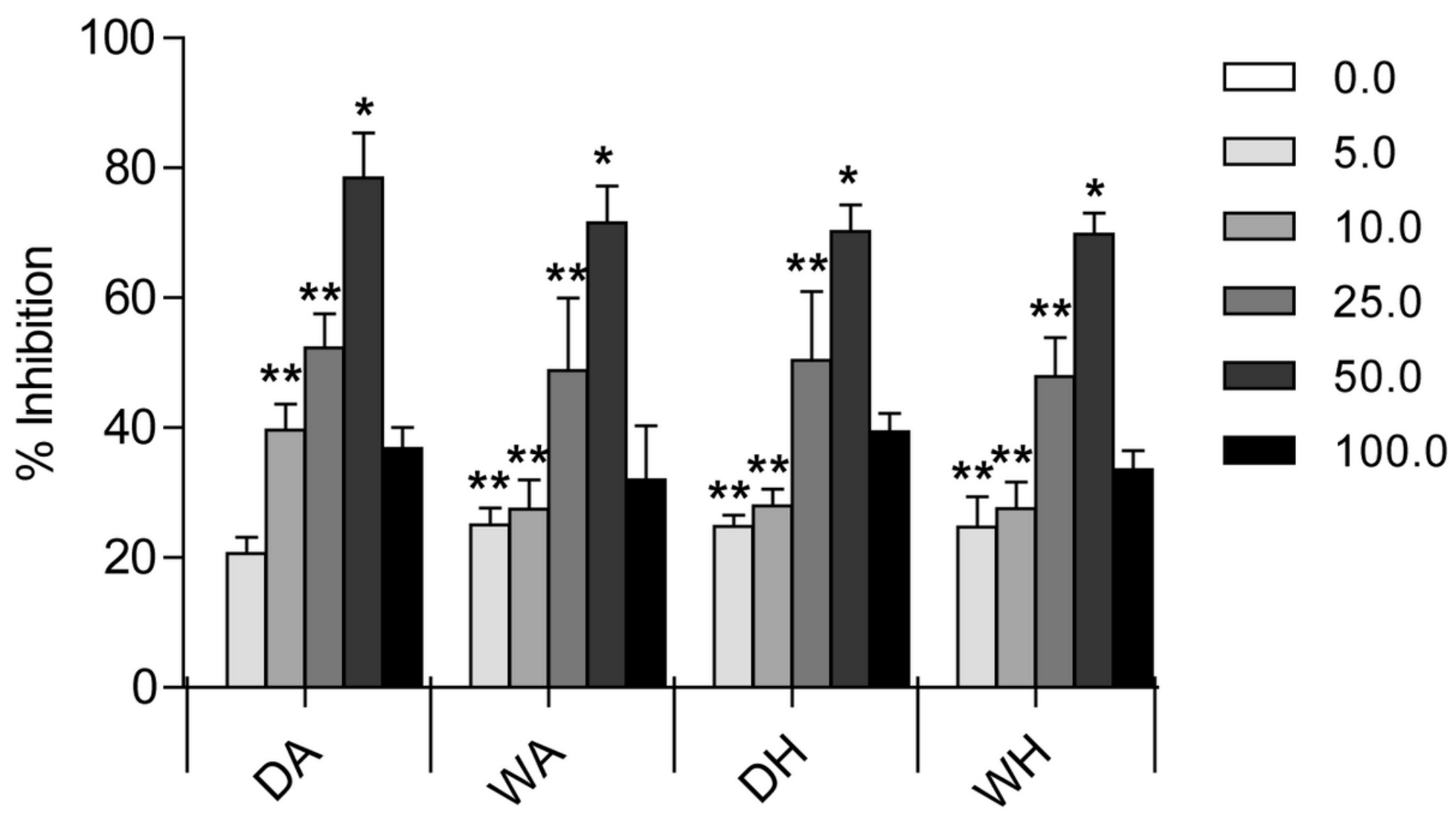

Extracts

Figure 4

Results of Ficopomatus enigmaticus AChE (acetylcholinesterase)-inhibitory activity when exposed to a range of concentrations (0.0, 5.0, 10.0, 25.0, 50.0 and $100.0 \mu \mathrm{g} / \mathrm{mL}$ ) of four different extracts (DA: dry sponges portioned with AcOEt, WA: wet sponges portioned with AcOEt., DH: dry sponges portioned with hexane, $\mathrm{WH}$ : wet sponges portioned with hexane). Results are expressed as a percentage. Mean $\pm \mathrm{SD}, \mathrm{p}<0.05(\star), \mathrm{p}<0.01(\star \star)$. 